\title{
Are folates, carotenoids and vitamin C affected by cooking? Four domestic procedures are compared on a large diversity of frozen vegetables
}

\author{
Sylvie Bureau ${ }^{\text {a, b, * , Sonia Mouhoubi }}{ }^{\text {a, b }}$, Line Touloumet ${ }^{\mathrm{a}, \mathrm{b}}$, Caroline Garcia ${ }^{\mathrm{a}, \mathrm{b}}$, \\ Florie Moreau ${ }^{c}$, Valérie Bédouet ${ }^{\mathrm{c}}$, Catherine M.G.C. Renard ${ }^{\mathrm{a}, \mathrm{b}}$ \\ a INRA, UMR408 Sécurité et Qualité des Produits d'Origine Végétale, F-84000 Avignon, France \\ ${ }^{\mathrm{b}}$ Université d'Avignon et des Pays de Vaucluse, UMR408 Sécurité et Qualité des Produits d'Origine Végétale, F-84000 Avignon, France \\ ' Toupargel, 13, chemin des près secs, 69380 Civrieux d'Azergues, France
}

Keywords:

Domestic cooking

Reprocessing

Nutritional quality

Vegetables

Ascorbate

\begin{abstract}
A B S T R A C T
Four home procedures such as boiling in water, steaming, pressure steaming and microwave cooking were tested on 13 frozen vegetables. Folates, carotenoids and vitamin $\mathrm{C}$ were characterized on uncooked and cooked vegetables and illustrated a very large variability among the studied vegetables. The effect of cooking was significant but it varied according to vegetables and phytochemicals. The best method to preserve the nutritional quality could be alternatively steaming, microwaving or pressure cooking, whereas boiling was generally the less suitable method. On the fresh weight basis, boiling involved a high loss of total vitamin C (average of $-51 \%$ on fresh matter) and folates $(-68 \%)$ and a slight loss of lutein $(-15 \%)$ and $\beta$-carotene $(-9 \%)$. On the dry weight basis, it remained the less suitable for vitamin $C$ $(-44 \%)$ and folates $(-65 \%)$ but not for carotenoids, as it allowed a better extractability of lutein $(+9 \%)$ and $\beta$-carotene $(+20 \%)$.
\end{abstract}

\section{Introduction}

Vegetables are a class of plant foods that are eaten as fresh, canned, frozen and cooked vegetables. Beyond its effect on texture and taste, cooking also changes the nutritional properties of vegetables. Main phytochemicals such as vitamin $C$, folates (vitamin B9) and provitamin A carotenoids ( $\beta, \alpha$ and $\gamma$-carotene and $\beta$ cryptoxanthin) are present in vegetables. Among non-vitaminic compounds, lutein (Calvo, 2005) and lycopene (Singh \& Goyal, 2008) are also mostly provided in the diet by green leafy vegetables and tomato, respectively. Lutein plays a major role against macula degeneration (Granado, Olmedilla, \& Blanco, 2003), while lycopene has proven effects in prevention of prostate cancer (Bramley, 2000).

The effect of domestic cooking on phytochemicals (carotenoids non-vitamin C, polyphenols, chlorophylls) and on micronutrients

* Corresponding author. INRA, UMR408 Sécurité et Qualité des Produits d'Origine Végétale, Centre de Recherche PACA, 228 route de l'Aérodrome, CS 40509, Domaine Saint Paul - Site Agroparc, 84914 Avignon Cedex 9, France.

E-mail address: sylvie.bureau@avignon.inra.fr (S. Bureau). (vitamins) and has been already studied on vegetables (Bernhardt \& Schlich, 2006; Gebczynski \& Lisiewska, 2006; Mazzeo et al., 2011; Miglio, Chiavaro, Visconti, Fogliano, \& Pellegrini, 2008; Pellegrini et al., 2010; Sultana, Anwar, \& Iqbal, 2008; Turkmen, Sari, \& Velioglu, 2005; Volden, Borge, Hansen, Wicklund, \& Bengtsson, 2009). Different procedures have been tested such as boiling, microwave cooking, steaming, pressure steaming, frying and stewing. Their effects have been observed on different families of phytochemicals i.e. total polyphenols, carotenoids, $\alpha$-tocopherol, glucosinolates, vitamin $\mathrm{C}$, anthocyanins and chlorophylls. A large diversity of vegetables has been concerned by these researches and it is encouraged to consume a large diversity of them to consume all nutrients and with a practical point of view to express the data on a dry weight basis to allow a good comparison taking into account the moisture change (Rickman et al., 2007a and b).

However data are fragmented because studies concern rarely all phytochemicals, usually on one or two vegetable species, and testing one or two of cooking methods, which makes difficult to have a good view of the effect of home cooking on the nutritional quality of vegetables. In addition, most of these studies have been focused on fresh vegetables, while modern lifestyles lead consumers to resort increasingly to processed vegetables (primarily 
canned and frozen). Frozen vegetables are convenient and, after the original reduction caused by blanching and freezing, maintain nutritional qualities levels at $-20{ }^{\circ} \mathrm{C}$ during storage for water soluble antioxidant activity in peas and spinach (Hunter \& Fletcher, 2002). However, our recent studies (Delchier, Reich, \& Renard, 2012) indicated that effects of cooking were exacerbated on frozen vegetables, mainly due to facilitated losses by leaching.

The aim of this work was to understand how an industrial processing (blanching and freezing) interacts with domestic cooking practices to impact the nutritional content of vegetables. Indeed, the effect of four common home cooking procedures, boiling in water, microwave cooking, steaming and pressure steaming, was studied on the micronutrient content of blanched and frozen vegetables. The representative micronutrients were hydrosoluble compounds such as vitamin $C$ and folates, and phytochemicals such as carotenoids for lipidic compounds. As different effects were highlighted depending on the vegetables (Danesi \& Bordoni, 2008), thirteen blanched and frozen vegetables, representative of a large diversity in composition and in shape, were characterized before and after cooking procedures.

\section{Materials and methods}

\subsection{Materials}

Thirteen vegetables were provided by a French company specialized in home delivery of frozen products (Toupargel, Civrieux d'Azergues). During their processing, vegetables were systematically blanched before freezing and then stored at $-20^{\circ} \mathrm{C}$. The studied vegetables were: (1) green and (2) yellow French bean (Phaseolus vulgaris L.), (3) pea (Pisum sativum L.), (4) Brussels sprout (Brassica oleracea L. Gemmifera group), (5) broccoli (B oleracea L. Italica group) and (6) cauliflower (B. oleracea L. Botrytis group), (7) leek (Allium porrum L.), (8) zucchini (Cucurbita pepo L. subsp. pepo), (9) branch (whole leaves) and (10) hashed spinach (Spinacia oleracea L.), (11) mushroom, despite not being vegetables they are treated by most consumers similarly (Agaricus bisporus (J.E.Lange) Imbach), (12) carrot (Daucus carota L.) and (13) salsify (Tragopogon porrifolius $\mathrm{L}$ ) were received in our laboratory in may 2012. For each, ten bags of $1 \mathrm{~kg}$ of the same batch were immediately stored at $-20^{\circ} \mathrm{C}$ until cooking.

\subsection{Four tested methods of home cooking}

Four home cooking methods were tested on $500 \mathrm{~g}$ of vegetables, following the recommendations indicated on the packaging by Toupargel, and following the instructions for use of the steamer (see $\S 2.2 .3$ ), of the pressure cooker, and of the microwave-oven. The frozen vegetables were ready to use, without thawing. For each method, three replications were performed on different portions of $500 \mathrm{~g}$ of vegetables but all portions were from the same batch of frozen vegetables. The cooking water was salted such as at home (around $10 \mathrm{~g} / \mathrm{L}$ ).

\subsubsection{Boiling water (BW)}

Each portion of frozen vegetables was immersed in boiling water in a pan at atmospheric pressure without lid. The volume of water and the time of cooking are given in Table 1. After boiling, vegetables were drained using a strainer, stabilized by freezing in liquid nitrogen and stored at $-80{ }^{\circ} \mathrm{C}$ until analysis.

\subsubsection{Pressure cooking $(P C)$}

Each portion of frozen vegetables was placed in a sealed pressure cooker (nutricook ${ }^{\circledR}$, SEB, Selongey, France) with 400 or $800 \mathrm{~mL}$ of water at the bottom of the cooker. Vegetables were kept out of the water during cooking. The time of cooking given in Table 1 corresponded to the time after the first issue of vapor. Just after cooking, vegetables were drained, chilled in an ice water bath during five minutes, drained, stabilized by freezing in liquid nitrogen and stored at $-80^{\circ} \mathrm{C}$ until analysis.

\subsubsection{Steaming $(S T)$}

As no recommendation was indicated on packaging, the cooking time was defined experimentally and collectively by 6 persons of the laboratory who tasted each vegetable after different cooking times. Each portion of frozen vegetables was steamed according to this defined time (Table 1 ). $1 \mathrm{~L}$ of water was used to generate the steam. Steaming was carried out using SEB "Vitacuisine Compact ${ }^{\circledR}$ " (SEB, Selongey, France). At the end of steaming, vegetables were directly stabilized by freezing in liquid nitrogen and stored at $-80^{\circ} \mathrm{C}$ until analysis.

\subsubsection{Microwave cooking (MW)}

In the microwave (Whirlpool, Family chef) no additional water was used. The vegetables were placed in a dish with a lid and were stirred at half of the cooking time (Table 1 ). Heating occurred with a power of $750 \mathrm{~W}$, i.e. $1.5 \mathrm{~W} / \mathrm{g}$. Vegetables were then stabilized by freezing in liquid nitrogen and stored at $-80^{\circ} \mathrm{C}$ until analysis.

\subsection{Samples preparation}

Before analysis, the frozen samples were ground in liquid nitrogen to obtain a homogenised powder which was stored at $-80^{\circ} \mathrm{C}$. In parallel to the cooking tests, three sets of $500 \mathrm{~g}$ of each uncooked vegetable, blanched and frozen, were directly taken in the marketed bags. They were ground in liquid nitrogen, stored at $-80^{\circ} \mathrm{C}$ until analyses. They corresponded to the 'control' samples identified by $\mathrm{T0}$.

For each sample, the dry weight was determined on sample powder (the same as used for nutrient analyses to ensure consistency) in a convection oven at $70{ }^{\circ} \mathrm{C}$ until constant weight was reached (about 3 days). The determined dry weight was used to calculate the nutrient content in dry weight (DW) basis from the analytical results obtained in fresh weight (FW) basis.

\subsection{Biochemical measurements}

Nutrient analyses were made directly on homogenised powder, stored at $-80^{\circ} \mathrm{C}$, without any defrosting.

\subsubsection{Chemicals}

Chemicals were the same that those already described by Delchier et al. (2013) for folates, by Page, Van Stratum, Degrou, and Renard (2012) for carotenoids and by Stevens, Buret, Garchery, Carretero, and Causse (2006) for vitamin C.

\subsubsection{Folates}

Folate extraction, deconjugation and derivatisation were carried out on frozen homogenised powder stored at $-80{ }^{\circ} \mathrm{C}$ using the principle described by Delchier et al. (2012). Among the 13 vegetables, folates were characterized in all vegetables at T0 but only in 4 vegetables (green bean, broccoli, hashed spinach and cauliflower) after the four cooking procedures because their analysis is workintensive and a number of vegetables had very low initial levels. Folate content was expressed as total folates in $\mu \mathrm{g} / \mathrm{kg}$ of fresh weight (FW) and calculated in $\mu \mathrm{g} / \mathrm{kg}$ of dry weight (DW).

\subsubsection{Carotenoids}

Carotenoid extraction was carried out on frozen homogenized powder stored at $-80{ }^{\circ} \mathrm{C}$ using the micromethod described by 
Version définitive du manuscrit publiée dans / Final version of the manuscript published in :

LWT - Food Science and Technology (2015), Vol. 64, p. 735-741, DOI: 10.1016/j.Iwt.2015.06.016

Journal homepage : http://www.elsevier.com/locate/lwt

Table 1

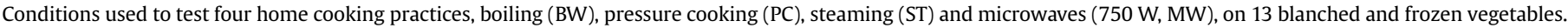

\begin{tabular}{|c|c|c|c|c|c|c|c|c|}
\hline \multirow{2}{*}{$\begin{array}{l}\text { Portion of vegetables } \\
(500 \mathrm{~g})\end{array}$} & \multicolumn{2}{|l|}{ BW } & \multicolumn{2}{|l|}{ PC } & \multicolumn{2}{|l|}{ ST } & \multicolumn{2}{|l|}{ MW } \\
\hline & Water volume L & $\begin{array}{l}\text { Cooking time } \\
\text { min }\end{array}$ & $\begin{array}{l}\text { Water volume } \\
\mathrm{mL}\end{array}$ & $\begin{array}{l}\text { Cooking time } \\
\text { min }\end{array}$ & Water volume L & $\begin{array}{l}\text { Cooking time } \\
\text { min }\end{array}$ & Water volume & $\begin{array}{l}\text { Cooking time } \\
\text { min }\end{array}$ \\
\hline Green bean & 1 & 9 & 400 & 3 & 1 & 30 & No & 18 \\
\hline Pea & 1 & 10 & 400 & 5 & 1 & 18 & No & 15 \\
\hline Brussels sprout & 1 & 11 & 400 & 6 & 1 & 25 & No & 15 \\
\hline Leek (slices) & 1 & 17 & 400 & 8 & 1 & 30 & No & 15 \\
\hline Broccoli & 2 & 6 & 800 & 6 & 1 & 20 & No & 10 \\
\hline Zucchini (slices) & 1 & 2 & 400 & 4 & 1 & 19 & No & 10 \\
\hline Spinach branch & 1 & 10 & 400 & 6 & 1 & 20 & No & 15 \\
\hline Hashed spinach & 1 & 15 & 400 & 6 & 1 & 20 & No & 12 \\
\hline Yellow French bean & 1 & 8 & 400 & 5 & 1 & 30 & No & 15 \\
\hline Cauliflower & 2 & 7 & 400 & 3 & 1 & 23 & No & 13 \\
\hline Mushroom & 1 & 5 & 400 & 3 & 1 & 15 & No & 10 \\
\hline Carrot (slices) & 1 & 9 & 400 & 4 & 1 & 20 & No & 15 \\
\hline Salsify & 1 & 16 & 400 & 8 & 1 & 32 & No & 13 \\
\hline
\end{tabular}

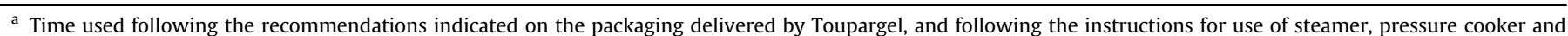
microwave-oven.

Sérino, Gomez, Costagliola, and Gautier (2009) and modified by Page et al. (2012). In this work, the internal standard was lycopene for green vegetables and $\beta$-apo- $\boldsymbol{~}^{\prime}$-carotenal for the others. Indeed, as $\beta$-apo- $8^{\prime}$-carotenal, the usual internal standard, co-eluted with chlorophylls, it was replaced by lycopene in green vegetables. $\beta$ carotene and lutein were quantified, both in $\beta$-carotene equivalent, expressed in $\mathrm{mg} / \mathrm{kg}$ FW and calculated in $\mathrm{mg} / \mathrm{kg}$ DW.

\subsubsection{Total vitamin $C$}

Vitamin $C$ was quantified in frozen homogenised powder stored at $-80{ }^{\circ} \mathrm{C}$ using a micro colorimetric method previously described (Stevens et al., 2006) with few modifications. Vitamin C was extracted from $500 \mathrm{mg}$ of vegetable powder. For each sample, two analytical repetitions were carried out and quantification was determined by an external calibration against ascorbic acid (Sigma Aldrich, France). Results are expressed in total vitamin $C$ i.e. the sum of ascorbic acid and dehydroascorbic acid in $\mathrm{mg} / \mathrm{kg}$ FW and calculated in $\mathrm{mg} / \mathrm{kg}$ DW.

\subsection{Statistical treatment}

Results are presented as mean values in $\mathrm{mg} / \mathrm{kg}$ FW and in $\mathrm{mg} / \mathrm{kg}$ DW for carotenoids and vitamin C and in $\mu \mathrm{g} / \mathrm{kg}$ FW and in $\mu \mathrm{g} / \mathrm{kg}$ DW for folates. The reproducibility of the results was expressed as pooled standard deviation values (Pooled SD) calculated as the square root of the sum of individual variances pondered by the individual degrees of freedom of each series of replicates (Box, Hunter, \& Hunter, 1978). ANOVA was carried out to determine significant differences between vegetables, cooking procedures and the possible interactions between these two factors using the XLSTAT $^{\odot}$ data analysis toolbox. The pairwise comparison between means was performed out using Tukey's test $\left(\mathrm{P}<0.05^{*}, 0.01^{* *}\right.$ and $\left.0.001^{* * *}\right)$.

\section{Results and discussion}

\subsection{Diversity of vegetable materials}

The chosen vegetables varied not only for their contents in folates, carotenoids and vitamin $C$ but also for their shape and tissue structure, which could affect the phytochemical behavior during cooking. We can group the vegetables according to their shape with 1) squat cylinder (slice): leek, zucchini, mushroom, carrot, 2) sphere: pea, Brussels sprout, broccoli, cauliflower, 3) thin cylinder: green bean, yellow French bean, salsify and 4) thin flat sheet: spinach branch, hashed spinach. These different shapes and surfaces/volume ratios are known to influence leaching of phytochemicals and for example the faster diffusion of folates in green beans than in spinach (Delchier, Ringling, Maingonnat, Rychlik, \& Renard, 2014).

In this study, the vegetables identified as T0 had been blanched and frozen before to be stored at $-20^{\circ} \mathrm{C}$. Their folate content was very low in carrot $(22 \mu \mathrm{g} / \mathrm{kg} \mathrm{FW})$ or in mushroom (38 $\mu \mathrm{g} / \mathrm{kg} \mathrm{FW})$ and was thirty times higher in spinach branch $(649 \mu \mathrm{g} / \mathrm{kg} \mathrm{FW})$ (Table 2, T0 lines). Folate contents found here were lower than those described for frozen spinach and green beans (Delchier et al., 2012). The difference between different data sets and literature could be due to the quality of raw materials (different varieties, cultural practices ...) and/or to the processing procedures. Mostly, in papers, no indication was given concerning the blanching (Delchier et al., 2012) and so conditions can not be compared.

Lutein was the main carotenoid in green vegetables, followed by $\beta$-carotene. Their contents varied from $3 \mathrm{mg} / \mathrm{kg} \mathrm{FW}$ in Brussels sprout to $110 \mathrm{mg} / \mathrm{kg} \mathrm{FW}$ in spinach branch for lutein and between 2 and $44 \mathrm{mg} / \mathrm{kg} \mathrm{FW}$ in the same vegetables for $\beta$-carotene (Table 2, T0 lines). Carrot is known for its high amount of $\beta$-carotene $(133 \mathrm{mg} /$ $\mathrm{kg}$ ) and yellow French beans only contained a little lutein $(0.7 \mathrm{mg} /$ $\mathrm{kg}$ FW). The white cauliflower, mushroom and salsify did not contain any $\beta$-carotene or lutein, as expected, considering their white coloration. Carotenoid contents observed in this study were in the range given in literature (Bernhardt \& Schlich, 2006; Delchier et al., 2012; Miglio et al., 2008; Pellegrini et al., 2010). The precise values reported here and in the literature are function of the raw material (variety or cultivation) or of the preparation procedures.

Vitamin C concentrations varied widely among studied vegetables, from its absence in salsify to $753 \mathrm{mg} / \mathrm{kg}$ in Brussels sprout (Table 2, T0 lines). Similar data are reported (Miglio et al., 2008). Higher concentrations were found in raw cauliflower (Volden et al., 2009) and in frozen cauliflower (Pellegrini et al., 2010). In accordance with Pellegrini et al. (2010), Brussels sprout are the richest in vitamin C. In mushroom, contradictory data are reported between absence to content varying between 3.7 and $6.7 \mathrm{mg} / \mathrm{g}$ of vitamin C (Mishra et al., 2013; Tsai et al., 2009). No data has been found for salsify.

The starting materials thus presented very different levels of the three types of analyzed phytochemicals. Because we started from a single batch of product each time, biological replicates had initially close concentrations, though the example of spinach highlighted the potential for major differences in initial content depending on raw material characteristics (variety, cultivation ...). 


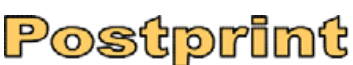

Version définitive du manuscrit publiée dans / Final version of the manuscript published in :

LWT - Food Science and Technology (2015), Vol. 64, p. 735-741, DOI: 10.1016/j.Iwt.2015.06.016

Journal homepage : http://www.elsevier.com/locate/lwt

Table 2

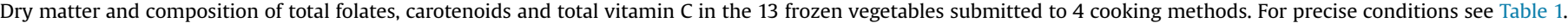

\begin{tabular}{|c|c|c|c|c|c|c|c|c|c|c|}
\hline \multicolumn{7}{|l|}{ Fresh weight (FW) } & \multicolumn{4}{|c|}{ Dry weight (DW) } \\
\hline \multirow[t]{2}{*}{ Vegetables } & \multirow[t]{2}{*}{ Cooking } & \multirow{2}{*}{$\begin{array}{l}\text { Dry matter } \\
(\mathrm{g} / \mathrm{kg})\end{array}$} & \multirow{2}{*}{$\begin{array}{l}\text { Total folates } \\
(\mu \mathrm{g} / \mathrm{kg})\end{array}$} & \multicolumn{2}{|l|}{ Carotenoids } & Total vitamin C & Total folates & Carotenoids & & Total vitamin $C$ \\
\hline & & & & $\beta$-carotene & Lutein & & & $\beta$-carotene & Lutein & (Im) \\
\hline Green bean & T0 & 92.0 & 113 & 3.9 & 10.9 & 90 & 1223 & 42 & 117 & 971 \\
\hline & BW & 83.0 & 83 & 2.5 & 7.0 & 60 & 997 & 30 & 84 & 725 \\
\hline & PC & 89.0 & 101 & 2.3 & 6.4 & 72 & 1128 & 26 & 72 & 803 \\
\hline & ST & 106.0 & 115 & 3.2 & 8.9 & 91 & 1091 & 30 & 84 & 858 \\
\hline & MW & 134.0 & 147 & 2.8 & 8.2 & 95 & 1097 & 21 & 62 & 708 \\
\hline & Pooled SD & 4.0 & 2.7 & 0.1 & 0.4 & 8 & 26 & 1 & 3 & 74 \\
\hline Pea & T0 & 196.0 & 243 & 5.4 & 32.8 & 219 & 1239 & 28 & 167 & 1115 \\
\hline & BW & 143.0 & - & 4.6 & 27.6 & 56 & - & 32 & 193 & 389 \\
\hline & PC & 161.0 & - & 4.5 & 26.3 & 109 & - & 28 & 163 & 677 \\
\hline & ST & 206.0 & - & 4.7 & 28.4 & 191 & - & 23 & 138 & 926 \\
\hline & MW & 248.0 & - & 4.7 & 28.0 & 227 & - & 19 & 113 & 917 \\
\hline & Pooled SD & 2.0 & - & 0.1 & 0.8 & 7 & - & 1 & 4 & 34 \\
\hline Brussels sprout & T0 & 107.0 & 176 & 2.0 & 3.1 & 753 & 1650 & 18 & 28 & 7058 \\
\hline & BW & 103.0 & - & 2.1 & 3.9 & 538 & - & 21 & 39 & 5233 \\
\hline & PC & 109.0 & - & 1.9 & 3.1 & 712 & - & 18 & 29 & 6529 \\
\hline & ST & 127.0 & - & 2.4 & 4.3 & 699 & - & 19 & 34 & 5486 \\
\hline & MW & 154.0 & - & 2.4 & 4.9 & 961 & - & 15 & 32 & 6261 \\
\hline & Pooled SD & 4.0 & - & 0.2 & 0.4 & 45 & - & 2 & 4 & 385 \\
\hline Leek (slices) & T0 & 87.0 & 436 & 4.9 & 15 & 56 & 5028 & 57 & 170 & 643 \\
\hline & BW & 61.0 & - & 6.1 & 21 & 5 & - & 102 & 354 & 89 \\
\hline & PC & 85.0 & - & 10.2 & 27 & 23 & - & 122 & 320 & 275 \\
\hline & ST & 110.0 & - & 8.4 & 25 & 39 & - & 76 & 223 & 357 \\
\hline & MW & 125.0 & - & 9.0 & 30 & 57 & - & 72 & 243 & 453 \\
\hline & Pooled SD & 3.0 & - & 1.1 & 2 & 7 & - & 13 & 28 & 80 \\
\hline Broccoli & T0 & 74.0 & 188 & 2.8 & 6.0 & 583 & 2540 & 38 & 81 & 7863 \\
\hline & BW & 60.0 & 76 & 4.1 & 10.7 & 213 & 1272 & 68 & 178 & 3543 \\
\hline & PC & 85.0 & 120 & 6.1 & 14.3 & 509 & 1420 & 72 & 170 & 6022 \\
\hline & ST & 102.0 & 283 & 5.1 & 13.0 & 746 & 2768 & 50 & 127 & 7283 \\
\hline & MW & 110.0 & 247 & 3.5 & 8.7 & 877 & 2241 & 31 & 78 & 7964 \\
\hline & Pooled SD & 3.0 & 14 & 0.4 & 1.1 & 52 & 180 & 3 & 9 & 577 \\
\hline Zucchini (slices) & T0 & 56.0 & 49 & 2.5 & 12.9 & 107 & 879 & 44 & 231 & 1912 \\
\hline & BW & 42.0 & - & 1.6 & 9.1 & 45 & - & 38 & 215 & 1075 \\
\hline & PC & 48.0 & - & 2.5 & 14.3 & 82 & - & 52 & 300 & 1717 \\
\hline & ST & 58.0 & - & 3.4 & 20.2 & 107 & - & 59 & 350 & 1863 \\
\hline & MW & 61.0 & - & 2.1 & 12.4 & 144 & - & 35 & 202 & 2350 \\
\hline & Pooled SD & 1.0 & - & 0.1 & 0.3 & 5 & - & 2 & 9 & 102 \\
\hline Spinach branch & T0 & 98.0 & 649 & 44.4 & 110 & 237 & 6600 & 459 & 1138 & 2411 \\
\hline & BW & 61.0 & - & 37.6 & 93 & 23 & - & 621 & 1539 & 385 \\
\hline & PC & 95.0 & - & 56.6 & 143 & 107 & - & 598 & 1513 & 1131 \\
\hline & ST & 106.0 & - & 58.8 & 133 & 176 & - & 557 & 1260 & 1662 \\
\hline & MW & 114.0 & - & 49.3 & 124 & 227 & - & 433 & 1091 & 1996 \\
\hline & Pooled SD & 5.0 & - & 1.1 & 2.6 & 10 & - & 21 & 50 & 101 \\
\hline Hashed spinach & T0 & 54.0 & 272 & 37 & 97 & 43 & 5076 & 698 & 1808 & 810 \\
\hline & BW & 46.0 & 15 & 27 & 70 & 0 & 322 & 591 & 1511 & 0 \\
\hline & PC & 62.0 & 106 & 57 & 124 & 2 & 1714 & 932 & 2023 & 32 \\
\hline & ST & 68.0 & 234 & 46 & 110 & 25 & 3419 & 668 & 1602 & 366 \\
\hline & MW & 73.0 & 241 & 44 & 113 & 29 & 3289 & 601 & 1537 & 398 \\
\hline & Pooled SD & 2.0 & 27 & 2 & 4 & 4 & 387 & 21 & 44 & 61 \\
\hline Yellow French bean & T0 & 95.0 & 95 & 0.0 & 0.7 & 112 & 1002 & 0 & 7 & 1174 \\
\hline & BW & 71.0 & - & 0.3 & 0.9 & 71 & - & 4 & 12 & 999 \\
\hline & PC & 80.0 & - & 0.2 & 0.9 & 84 & - & 2 & 11 & 1050 \\
\hline & ST & 98.0 & - & 0.5 & 1.2 & 108 & - & 5 & 13 & 1093 \\
\hline & MW & 115.0 & - & 0.5 & 1.1 & 127 & - & 4 & 10 & 1108 \\
\hline & Pooled SD & 2.0 & - & 0.1 & 0.1 & 10 & - & 1 & 1 & 90 \\
\hline Cauliflower & T0 & 68.0 & 170 & 0 & 0 & 337 & 2512 & 0 & 0 & 4982 \\
\hline & BW & 58.0 & 77 & 0 & 0 & 223 & 1326 & 0 & 0 & 3854 \\
\hline & PC & 65.0 & 120 & 0 & 0 & 305 & 1841 & 0 & 0 & 4667 \\
\hline & ST & 80.0 & 134 & 0 & 0 & 373 & 1677 & 0 & 0 & 4666 \\
\hline & MW & 88.0 & 127 & 0 & 0 & 386 & 1442 & 0 & 0 & 4392 \\
\hline & Pooled SD & 3.0 & 7.6 & 0 & 0 & 30 & 106 & 0 & 0 & 454 \\
\hline Mushroom & T0 & 36.0 & 38 & 0 & 0 & 0.8 & 1029 & 0 & 0 & 22 \\
\hline & BW & 38.0 & - & 0 & 0 & 0.0 & - & 0 & 0 & 0 \\
\hline & PC & 44.0 & - & 0 & 0 & 1.3 & - & 0 & 0 & 30 \\
\hline & ST & 57.0 & - & 0 & 0 & 0.0 & - & 0 & 0 & 0 \\
\hline & MW & 53.0 & - & 0 & 0 & 5.3 & - & 0 & 0 & 101 \\
\hline & Pooled SD & 1.0 & - & 0 & 0 & 2.5 & - & 0 & 0 & 48 \\
\hline Carrot (slices) & T0 & 93.0 & 22 & 134 & 0 & 19.0 & 241 & 1435 & 0 & 204 \\
\hline & BW & 64.0 & - & 129 & 0 & 0.0 & - & 2031 & 0 & 0 \\
\hline & PC & 77.0 & - & 114 & 0 & 6.1 & - & 1475 & 0 & 79 \\
\hline & ST & 96.0 & - & 147 & 0 & 17.6 & - & 1523 & 0 & 183 \\
\hline & MW & 114.0 & - & 152 & 0 & 25.8 & - & 1329 & 0 & 226 \\
\hline
\end{tabular}


Version définitive du manuscrit publiée dans / Final version of the manuscript published in :

LWT - Food Science and Technology (2015), Vol. 64, p. 735-741, DOI: 10.1016/j.Iwt.2015.06.016

Journal homepage : http://www.elsevier.com/locate/lwt

Table 2 (continued)

\begin{tabular}{|c|c|c|c|c|c|c|c|c|c|c|}
\hline \multicolumn{7}{|c|}{ Fresh weight (FW) } & \multicolumn{4}{|c|}{ Dry weight (DW) } \\
\hline \multirow[t]{2}{*}{ Vegetables } & \multirow[t]{2}{*}{ Cooking } & \multirow{2}{*}{$\begin{array}{l}\text { Dry matter } \\
(\mathrm{g} / \mathrm{kg})\end{array}$} & \multirow{2}{*}{$\begin{array}{l}\text { Total folates } \\
(\mu \mathrm{g} / \mathrm{kg})\end{array}$} & \multicolumn{2}{|l|}{ Carotenoids } & \multirow{2}{*}{$\begin{array}{l}\text { Total vitamin } \mathrm{C} \\
(\mathrm{mg} / \mathrm{kg})\end{array}$} & \multirow{2}{*}{$\begin{array}{l}\text { Total folates } \\
(\mu \mathrm{g} / \mathrm{kg})\end{array}$} & \multicolumn{2}{|l|}{ Carotenoids } & \multirow{2}{*}{$\begin{array}{l}\text { Total vitamin C } \\
(\mathrm{mg} / \mathrm{kg})\end{array}$} \\
\hline & & & & $\beta$-carotene & Lutein & & & $\beta$-carotene & Lutein & \\
\hline & Pooled SD & 1.0 & - & 8 & 0 & 1.2 & - & 94 & 0 & 12 \\
\hline \multirow[t]{6}{*}{ Salsify } & T0 & 90.0 & 86 & 0 & 0 & 0.0 & 948 & 0 & 0 & 0 \\
\hline & BW & 85.0 & - & 0 & 0 & 0.0 & - & 0 & 0 & 0 \\
\hline & PC & 93.0 & - & 0 & 0 & 0.0 & - & 0 & 0 & 0 \\
\hline & ST & 105.0 & - & 0 & 0 & 0.0 & - & 0 & 0 & 0 \\
\hline & MW & 117.0 & - & 0 & 0 & 0.2 & - & 0 & 0 & 2 \\
\hline & Pooled SD & 6.0 & - & 0 & 0 & 0.1 & - & 0 & 0 & 1 \\
\hline \multirow[t]{5}{*}{ Statistics } & T0 & $88 \mathrm{c}$ & $0.19 \mathrm{a}$ & $18 \mathrm{bc}$ & $32 \mathrm{c}$ & $197 \mathrm{~b}$ & $2.84 \mathrm{a}$ & $217 \mathrm{bc}$ & $416 \mathrm{c}$ & $2243 \mathrm{a}$ \\
\hline & BW & $70 \mathrm{e}$ & $0.06 \mathrm{c}$ & $17 \mathrm{c}$ & $27 \mathrm{~d}$ & $95 \mathrm{~d}$ & $0.98 \mathrm{~d}$ & 272 a & $458 \mathrm{~b}$ & $1253 \mathrm{~d}$ \\
\hline & PC & $84 \mathrm{~d}$ & $0.11 \mathrm{~b}$ & $20 \mathrm{ab}$ & $40 \mathrm{a}$ & $155 c$ & $1.52 \mathrm{c}$ & $256 a$ & $511 \mathrm{a}$ & $1770 \mathrm{c}$ \\
\hline & ST & $102 \mathrm{~b}$ & $0.19 \mathrm{a}$ & $21 \mathrm{a}$ & $38 \mathrm{~b}$ & $198 \mathrm{~b}$ & $2.24 \mathrm{~b}$ & $232 \mathrm{~b}$ & $426 \mathrm{c}$ & 1903 bc \\
\hline & MW & $11.6 \mathrm{a}$ & $0.19 \mathrm{a}$ & $21 \mathrm{a}$ & $37 \mathrm{~b}$ & $243 a$ & $2.02 \mathrm{~b}$ & $198 \mathrm{c}$ & $374 \mathrm{~d}$ & $2067 \mathrm{ab}$ \\
\hline \multicolumn{11}{|c|}{ F-values and significance } \\
\hline & Vegetable & $641^{* * *}$ & $24^{* * *}$ & $1317^{* * *}$ & $2641^{* * *}$ & $585^{* * *}$ & $49^{* * *}$ & $1349^{* * *}$ & $3166^{* * *}$ & $474^{* * *}$ \\
\hline & Cooking & $382^{* * *}$ & $54^{* * *}$ & $9^{* * *}$ & $65^{* * *}$ & $87^{* * *}$ & $41^{* * *}$ & $15^{* * *}$ & $39^{* * *}$ & $33^{* * *}$ \\
\hline & veg. $\times$ cook & $10^{* * *}$ & $10^{* * *}$ & $6^{* * *}$ & $21^{* * *}$ & $12^{* * *}$ & $13^{* * *}$ & $10^{* * *}$ & $17^{* * *}$ & $5^{* * *}$ \\
\hline
\end{tabular}

Means of three replicates.

Means of three replicates; T0: initial blanched frozen vegetable; BW: boiled in water; PC: steamed in pressure-cooker; ST: steamed; MW: microwaves.

\subsection{Effect of domestic cooking procedures on vegetable nutritional quality}

Results of ANOVA revealed a significant effect of the vegetables and of the cooking procedures on nutritional quality of vegetables such as folates, carotenoids and vitamin C in $\mu$ g or $\mathrm{mg} / \mathrm{kg}$ FW and DW (Table 2). The F-values were higher for vegetables than for cooking procedures, especially for carotenoid and vitamin C suggesting a stronger effect of the genetic variability than of cooking on the nutritional vegetable quality. However, it was not the case for folates, for which, the F-values were close between the vegetable variability and the cooking procedures. Indeed for folates, the effect of vegetables variability was very low in comparison to the other metabolites. This is likely due to the systematic presence of folates in all vegetables as a key element of primary metabolism in living tissues. On the contrary, carotenoids, linked to photosynthesis and pigmentation, are absent in uncolored vegetables such as cauliflower and salsify, and in mushroom, the latter not being a plant. More surprisingly, vitamin $C$ was absent in salsify. Moreover concerning the effect of cooking, the F-values increased in the following order: $\beta$-carotene $<$ folates $<$ lutein $<$ vitamin $\mathrm{C}$ in FW and in the following order: $\beta$-carotene $<$ vitamin $C<$ lutein $<$ folates in DW. So the effect of cooking depended a) on the metabolites and $b$ ) on the expression in $\mathrm{mg} / \mathrm{kg}$ in FW or in DW in relation to the water loss (or gain) by vegetables during cooking.

\subsubsection{Effect of cooking procedures on dry matter}

Dry matter varied between $46 \mathrm{~g} / \mathrm{kg}$ in mushroom and $191 \mathrm{~g} / \mathrm{kg}$ in pea (Table 2) and was modified by the cooking procedure. A significant effect of cooking procedures was observed on dry matter in the following order: boiling in water (average over all vegetables $70 \mathrm{~g} / \mathrm{kg})<$ Pressure cooking $(84 \mathrm{~g} / \mathrm{kg})<\mathrm{T0}(88 \mathrm{~g} / \mathrm{kg})<$ Steaming $(102 \mathrm{~g} / \mathrm{kg})<$ Microwaves $(116 \mathrm{~g} / \mathrm{kg})$. In comparison with T0, pressure cooking and boiling led to an increase of vegetable water content whereas steaming and microwaves led to its decrease. This aspect is not much discussed in papers. Measurement of dry matter is usually made in order to express the content of studied metabolites in the dry weight basis and not to evaluate the effect of cooking procedures on water content as a quality trait of vegetables. However, similar results are observed on spinach (Delchier et al., 2012), though with a less marked effect on green bean than in our study. In the same way, boiling water, pressure cooking and microwaves did not greatly impact the dry matter of beans and radish (Kala \& Prakash, 2006).

\subsubsection{Effect of cooking procedures on metabolites}

\section{a Folates}

Folates were well preserved by steaming and microwaving, with the same concentrations in FW after cooking than T0 (Table 2). Pressure cooking caused their losses and even more water boiling. In average over all vegetables, pressure cooking caused a loss of folates of $10 \%$ in green bean and $61 \%$ in hashed spinach whereas boiling caused a loss of $26 \%$ in green bean and $94 \%$ in hashed spinach. Delchier et al. (2012) report the highest loss of folates in boiled spinach but not in green beans. In DW, the same trend was observed with the highest loss of folates in boiled vegetables representing a loss of $18 \%$ in green bean and $93 \%$ in hashed spinach.

\section{b Carotenoids}

Domestic cooking increased the carotenoid content in comparison with T0, except for water boiling (Table 2). It is known that the carotenoid extractability may be influenced by cooking, but it can be enhanced or not, with in some cases some detrimental effects (Ahmed \& Ali, 2013; Martínez-Hernández, Artés-Hernández, Gómez, \& Artés, 2013; Pellegrini et al., 2010; Pugliese et al., 2013). The effect of cooking was slightly different for $\beta$-carotene and lutein. For lutein, pressure cooking was the best followed by steaming and microwaving. For $\beta$-carotene, steaming and microwaves cooking were the best followed by pressure cooking. In general, for carotenoids, pressure cooking, steaming and microwaving increased their concentrations in comparison to the uncooked vegetables, but boiling water caused a slight loss. De La Cruz-Garcí;a et al. (1997) report on green beans increased detected concentration for all cooking methods, with a similar impact of the different treatments for lutein while for $\beta$-carotene, the increase is higher in boiling and steaming than in microwave and pressure cooking. In DW, in opposition to hydrophilic compounds, for lipophilic carotenoids, the pressure cooking and boiling (the highest concentrations) contrasted most with microwaving (the lowest concentration), with a difference of $27 \%$ on average for both, lutein and $\beta$-carotene (Table 2). However, the apparent loss of the two compounds by microwave cooking was only of $10 \%$ in 
comparison with T0. This highlights the fact that the water loss or gain during processing also plays a role in the interpretation of phytochemical behavior. Because microwave cooking causes loss of water, the actual breakdown of carotenoid molecules, visible on the DW basis was marked on the FW basis.

\section{c Vitamin C}

Vitamin C was well preserved by steaming and microwaving in comparison with T0 whereas pressure cooking and boiling water caused its losses (Table 2). Its behavior was similar to hydrophilic folates. In average over all vegetables, pressure cooking led to a loss of $21 \%$ of vitamin $C$ and boiling water of $51 \%$. Hunter and Fletcher (2002) also record for vitamin C in pea and spinach limited losses after microwaving and marked losses by boiling. In DW, the highest content of vitamin $\mathrm{C}$ was observed in $\mathrm{T} 0$, followed by microwaved and steamed. The maximum loss was observed in boiling water, in accordance with the folate behavior.

The discrimination of metabolites was shown by the fact that the content of water soluble compounds such as folates and vitamin $\mathrm{C}$ were very decreased by boiling and liberated in the aqueous phase in opposition with carotenoids, soluble in fat, not affecting by boiling. Moreover boiling promoted the extractability of $\beta$-carotene and lutein in comparison with $\mathrm{T} 0$, probably contributing to the measured apparent increase of their concentrations.

\subsubsection{Variable effects depending on cooking procedures and vegetables}

The interactions between the two factors, vegetables and cooking procedures, were all significant (Table 2). In other words, the simple main effects of cooking on some vegetables were different from the main general effect of cooking. This suggested that it will be difficult to establish a single rule to describe the impact of domestic cooking procedures on vegetable quality in relation to the numerous reactions involved and various vegetable characteristics. To explain the observed significant interactions, it is necessary to study the change of metabolite concentration individually for each vegetable during the cooking procedures:

- Concerning folates, the best cooking was steaming for broccoli and microwaving for green bean with a higher content than T0 whereas for cauliflower and spinach, steaming and microwaving were the best cooking but with a loss in comparison with T0 (Table 2, FW). In all cases, boiling in water affected the most the folate content. With their hydrophilic properties, folates can be easily lost in water by leaching. Delchier et al. (2012) report that half of the initial folate content for frozen spinach and 20\% for frozen green bean are recovered in the boiling water.

- Concerning carotenoids, the main differences appeared for carrot and spinach presenting the highest content (Table 2, FW). For spinach branch, steaming preserved $\beta$-carotene the best and actually even increased its measured concentration compared to T0 $(+24 \%)$. For hashed spinach, it was the pressure cooking $(+34 \%)$ and for carrot the microwave cooking $(+12 \%)$. The same trend was observed for lutein. Pressure cooking increases the more its content in broccoli, spinach branch and hashed spinach ( $+21-58 \%)$, microwave cooking in leek and Brussels sprout (+36-51\%) and steaming in zucchini (36\%). Generally, boiling water is the less suitable in comparison with the other cooking procedures even though in most cases the measured concentration remains higher than T0. According to Pellegrini et al., 2010, the significant carotenoid release in comparison with fresh vegetables is due to the tissue softening and to the denaturation of the carotenoid-protein complexes of chloroplasts and then to the increased extractability of these compounds. In comparison with the frozen vegetables, the blanching before freezing already involves this tissue softening and improves carotenoid extractability and thus, the following cooking methods don't allow a new further improved release of carotenoids. In our case, in FW and DW, the carotenoid contents were higher in cooked broccoli, whatever the methods, than in blanched and frozen T0 except for microwave in DW. Their lipophilic property must limit their leaching in water. Nevertheless the slight decrease of carotenoids expressed in FW (Bernhardt \& Schlich, 2006) or in DW (Pellegrini et al., 2010) occurring during all cooking treatments results from their leaching and heat damage. In blanched and frozen carrot, Mazzeo et al. (2011) observe a decrease of $\beta$-carotene content (in DW) by steaming and boiling but, in comparison with raw carrot, the boiling involves an increase of $14 \%$ of $\beta$-carotene (Miglio et al., 2008). The authors explain that temperature is the major factor affecting the carotenoid stability. In our conditions, only the microwave cooking induced a degradation of $\beta$-carotene which could be explained by an effect of a higher temperature.

- Concerning vitamin C, the generalization of observations appeared to be easier, since most vegetables had the same behavior: the vitamin $\mathrm{C}$ concentration (relative to $\mathrm{FW}$ ) was the highest with microwave cooking, except for spinach presenting the highest values in T0, and was the lowest with boiling water (Table 2, mg/kg FW). Boiling causes a higher loss for frozen vegetables than the other cooking procedures (Bernhardt \& Schlich, 2006; Pellegrini et al., 2010; Volden et al., 2009). The particularity of spinach is its high surface to volume ratio and so a high susceptibility to cooking treatments (Mazzeo et al., 2011). In general the lost vitamin $C$ is recovered in a large part in the processing water (Volden et al., 2009), due to its high water solubility. The little part of non recovered vitamin C, 2-10\% according to the cooking procedures, could be due to degradation in relation to its low thermal stability (Volden et al., 2009).

\subsection{Is there an effect of vegetable shape?}

This study concerned a large vegetable variability of vegetables, including different shapes such as squat cylinder (slice), sphere, thin cylinder and thin flat sheet. The vegetable shapes affected significantly the effect of cooking on nutritional metabolites (results not shown), with Fisher values $(F)$ of 8 for folates (significance ${ }^{* *}$ ), 230 for $\beta$-carotene (significance ${ }^{* * *}$ ), 143 for lutein (significance ${ }^{* * *}$ ) and 99 for vitamin C (significance ${ }^{* * *}$ ). The effects can be classified according to the following orders:

- for folates: sheet $(-94 \%$ in hashed spinach $)>$ sphere $(-55 \%$ in cauliflower and $-60 \%$ in broccoli) $>$ cylinder $(-27 \%$ in green bean),

- for carotenoids: sheet $>$ slices $>$ sphere $\sim$ cylinder for carotenoids ( $\beta$-carotene and lutein)

- and, for total vitamin C: sheet (-90\% in spinach branch to $-100 \%$ in hashed spinach) $>$ slice $(-57 \%$ in zucchini to $-100 \%$ in carrot and mushroom) $>$ sphere (from $-28 \%$ in Brussels sprouts to $-74 \%$ in peas) $>$ cylinder $(-30-40 \%$ in green and yellow beans).

The order varied with the different metabolites, but generally the cylinder form better preserved the nutritional quality than the sheet form, in accordance with Delchier et al. (2012). 


\section{Conclusion}

Domestic cooking practices strongly affected the nutritional quality of all 13 frozen vegetables. Four home cooking procedures and three classes of phytochemicals were tested and revealed the difficulty for establishing an order between the more and less suitable procedures. This has two main reasons: i) folates, carotenoids and vitamin $C$ presented different levels of sensitivity and ii) effects were strongly dependent on the vegetables. However, all vegetables combined, on the fresh weight basis, boiling was the less suitable method, with a high loss of vitamin C $(-51 \%)$ and folates $(-68 \%)$ and a slight loss of lutein $(-15 \%)$ and $\beta$-carotene $(-9 \%)$. On the dry weight basis, boiling remained the less suitable for vitamin C $(-44 \%)$ and folates $(-65 \%)$ but not for carotenoids. It led to a better extractability of lutein $(+9 \%)$ and $\beta$-carotene $(+20 \%)$. Depending on the vegetables and phytochemicals, steaming, microwaving or pressure cooking could be the best method to preserve the nutritional quality.

The absence of general results for all components and all vegetables (except for boiling) highlights the difficulty in giving a simple real recommendation for the cook to best preserve the nutritional quality of frozen vegetables.

\section{Acknowledgments}

This study was supported by the French company Toupargel.

\section{References}

Ahmed, F. A., \& Ali, R. F. M. (2013). Bioactive compounds and antioxidant activity of fresh and processed white cauliflower. BioMedical Research International, 2013, 9.

Bernhardt, S., \& Schlich, E. (2006). Impact of different cooking methods on food quality: retention of lipophilic vitamins in fresh and frozen vegetables. Journal of Food Engineering, 77, 327-333.

Box, G. E. P., Hunter, W. G., \& Hunter, J. S. (1978). Statistics for experimenters, an introduction to design, data analysis and model building (p. 352). New York: Wiley and Sons.

Bramley, P. M. (2000). Is lycopene beneficial to human health? Phytochemistry, 54(3), 233-236.

Calvo, M. M. (2005). Lutein: a valuable ingredient of fruit and vegetables. Critical Reviews in Food Science and Nutrition, 45(7-8), 671-696.

Danesi, F., \& Bordoni, A. (2008). Effect of home freezing and Italian style of cooking on antioxidant activity of edible vegetables. Journal of Food Science, 73, H109-H112.

De La Cruz-García, C., González-Castro, M. A. J., Oruña-Concha, M. A. J., LópezHernández, J., Simal-Lozano, J..Á., \& Simal-Gándara, J. (1997). The effects of various culinary treatments on the pigment content of green beans (Phaseolus vulgaris L.). Food Research International, 30, 787-791.

Delchier, N., Reich, M., \& Renard, C. M. G. C. (2012). Impact of cooking methods on folates, ascorbic acid and lutein in green beans (Phaseolus vulgaris) and spinach (Spinacea oleracea). LWT - Food Science and Technology, 49, 197-201.

Delchier, N., Ringling, C., Le Grandois, J., Aoudé-Werner, D., Galland, R., Georgé, S., et al. (2013). Effects of industrial processing on folate content in green vegetables. Food Chemistry, 139, 815-824.

Delchier, N., Ringling, C., Maingonnat, J.-F., Rychlik, M., \& Renard, C. M. G. C. (2014) Mechanisms of folate losses during processing: diffusion vs. heat degradation. Food Chemistry, 157, 439-447.
Gebczynski, P., \& Lisiewska, Z. (2006). Comparison of the level of selected antioxidative compounds in frozen broccoli produced using traditional and modified methods. Innovative Food Science \& Emerging Technologies, 7(3), 239-245.

Granado, F., Olmedilla, B., \& Blanco, I. (2003). Nutritional and clinical relevance of lutein in human health. British Journal of Nutrition, 90(3), 487-502.

Hunter, K. J., \& Fletcher, J. M. (2002). The antioxidant activity and composition of fresh, frozen, jarred and canned vegetable. Innovative Food Science Emerging Technology, 3, 399-406.

Kala, A., \& Prakash, J. (2006). The comparative evaluation of the nutrient composition and sensory attributes of four vegetables cooked by different methods. International Journal of Food Science \& Technology, 41, 163-171.

Martínez-Hernández, G. B., Artés-Hernández, F., Gómez, P. A., \& Artés, F. (2013). Quality changes after vacuum-based and conventional industrial cooking of kailan-hybrid broccoli throughout retail cold storage. LWT - Food Science and Technology, 50, 707-714.

Mazzeo, T., N'Dri, D., Chiavaro, E., Visconti, A., Fogliano, V., \& Pellegrini, N. (2011). Effect of two cooking procedures on phytochemical compounds, total antioxidant capacity and colour of selected frozen vegetables. Food Chemistry, 128, 627-633.

Miglio, C., Chiavaro, E., Visconti, A., Fogliano, V., \& Pellegrini, N. (2008). Effects of different cooking methods on nutritional and physicochemical characteristics of selected vegetables. Journal of Agricultural and Food Chemistry, 56, 139-147.

Mishra, K. K., Pal, R. S., ArunKumar, R., Chandrashekara, C., Jain, S. K., \& Bhatt, J. C. (2013). Antioxidant properties of different edible mushroom species and increased bioconversion efficiency of Pleurotus eryngii using locally available casing materials. Food Chemistry, 138, 1557-1563.

Page, D., Van Stratum, E., Degrou, A., \& Renard, C. M. G. C. (2012). Kinetics of temperature increase during tomato processing modulate the bioaccessibility of lycopene. Food Chemistry, 135, 2462-2469.

Pellegrini, N., Chiavaro, E., Gardana, C., Mazzeo, T., Contino, D., Gallo, M., et al. (2010). Effect of different cooking methods on color, phytochemical concentration, and antioxidant capacity of raw and frozen Brassica vegetables. Journal of Agricultural and Food Chemistry, 58, 4310-4321.

Pugliese, A. Loizzo, M. R. Tundis, R., O'Callaghan, Y, Galvin, K. Menichini, F, et al, (2013). The effect of domestic processing on the content and bioaccessibility of carotenoids from chili peppers (Capsicum species). Food Chemistry, 141, 2606-2613.

Rickman, J., Barrett, D., \& Bruhn, C. (2007a). Nutritional comparison of fresh, frozen and canned fruits and vegetables. Part 1 . Vitamins C and B and phenolic compounds. Journal of the Science of Food and Agriculture, 87(6), 930-944.

Rickman, J., Bruhn, C., \& Barrett, D. (2007b). Nutritional comparison of fresh, frozen, and canned fruits and vegetables II. Vitamin A and carotenoids, vitamin E, minerals and fiber. Journal of the Science of Food and Agriculture, 87(7), 1185-1196.

Sérino, S., Gomez, L., Costagliola, G., \& Gautier, H. (2009). HPLC assay of tomato carotenoids: validation of a rapid microextraction technique. Journal of Agricultural and Food Chemistry, 57, 8753-8760.

Singh, P., \& Goyal, G. K. (2008). Dietary lycopene: its properties and anticarcinogenic effects. Comprehensive Reviews in Food Science and Food Safety, 7(3), 255-270.

Stevens, R., Buret, M., Garchery, C., Carretero, Y., \& Causse, M. (2006). Technique for rapid, small-scale analysis of vitamin $C$ levels in fruit and application to a tomato mutant collection. Journal of Agricultural and Food Chemistry, 54, 6159-6165.

Sultana, B., Anwar, F., \& Iqbal, S. (2008). Effect of different cooking methods on the antioxidant activity of some vegetables from Pakistan. International Journal of Food Science \& Technology, 43, 560-567.

Tsai, S.-Y., Huang, S.-J., Lo, S. H., Wu, T.-P., Lian, P.-Y., \& Mau, J.-L. (2009). Flavour components and antioxidant properties of several cultivated mushrooms. Food Chemistry, 113, 578-584.

Turkmen, N., Sari, F., \& Velioglu, Y. S. (2005). The effect of cooking methods on total phenolics and antioxidant activity of selected green vegetables. Food Chemistry, 93, 713-718.

Volden, J., Borge, G. I. A., Hansen, M., Wicklund, T., \& Bengtsson, G. B. (2009). Processing (blanching, boiling, steaming) effects on the content of glucosinolates and antioxidant-related parameters in cauliflower (Brassica oleracea L. ssp. botrytis). LWT - Food Science and Technology, 42, 63-73. 